\title{
The Implementation of Minimum Wage Establishment Based on Law Number 13 of 2003 Concerning Manpower
}

\author{
Nona Rizki Nusantara, Dikha Anugrah and Anthon Fathanudien \\ Fakulty of Law, Universitas Kuningan, Indonesia \\ E-mail: nonarizki@gmail.com
}

How to cite : Nona Rizki Nusantara, Dikha Anugrah and Anthon Fathanudien. (2019). The Implementation of Minimum Wage Establishment Based on Law Number 13 of 2003 Concerning Manpower. UNIFIKASI : Jurnal IImu Hukum. 6(1), 101-115. DOI : 10.25134/unifikasi.v6i1.707

Submitted : 07-11-2018 Revised : 31-05-2019

Accepted : 15-06-2019

\begin{abstract}
This study aims to analyze the procedure of minimum wage establishment based on Law No. 13 of 2003 concerning Manpower as well as the implementation of minimum wage establishment based on Law No. 13 of 2003 in Kuningan District. The method used in this study was a descriptive analytical method with an empirical juridical approach. The data were collected through interviews and literature study with data collection tool in the form of field notes. The data were then analyzed by applying qualitative analysis technique. As results, it was revealed that the procedure of minimum wage establishment is based on Law No. 13 of 2003 concerning Manpower in which the establishment of minimum wage is directed towards meeting the decent living needs. The minimum wage is established by the Governor after considering the recommendations provided by Provincial Wage Councils and/or District Heads/Mayors. Meanwhile, the components of and the implementation of the phases of achieving the decent living needs are specified and determined with a Ministerial Decision. Briefly, in general, the implementation of minimum wage establishment which is based on Law No. 13 of 2003 in Kuningan District is quite good since the minimum wage establishment is regulated by the Governor with the consideration that the Governor is more aware of the social, economic and employment conditions in West Java.
\end{abstract}

Keywords: The Procedure of Minimum Wage Establishment; General Prosperity.

\section{Implementasi Penetapan Upah Minimum Berdasarkan Undang-Undang Nomor 13 Tahun 2003 tentang Ketenagakerjaan}

\begin{abstract}
Abstrak : Tujuan penelitian ini adalah untuk mengetahui prosedur penetapan upah minimum berdasarkan Undang-Undang Nomor 13 Tahun 2003 tentang Ketenagakerjaan serta implementasi penetapan upah minimum berdasarkan Undang-Undang Nomor 13 Tahun 2003 di Kabupaten Kuningan. Metode penelitian yang digunakan adalah metode deskriptif analitis dengan pendekatan yuridis empiris. Teknik pengumpul data yang digunakan dalam penelitian ini adalah wawancara dan studi kepustakaan dengan alat pengumpul data berupa catatan lapangan. Data penelitian dianalisis dengan menggunakan teknik analisis kualitatif. Hasil penelitian menunjukkan bahwa prosedur penetapan upah minimum berdasarkan Undang-Undang Nomor 13 Tahun 2003 tentang Ketenagakerjaan bahwa upah minimum diarahkan kepada pencapaian kebutuhan hidup layak. Upah minimum ditetapkan oleh Gubernur dengan memperhatikan rekomendasi dari Dewan Pengupahan Provinsi dan/atau Bupati/Walikota. Komponen serta pelaksanaan tahapan pencapaian kebutuhan hidup layak diatur dengan Keputusan Menteri; serta implementasi penetapan upah minimum berdasarkan Undang-Undang Nomor 13 Tahun 2003 di Kabupaten Kuningan secara umum cukup baik sebagaimana penetapan upah minimum ditetapkan oleh Gubernur dengan pertimbangan bahwa Gubernur lebih mengetahui kondisi sosial, ekonomi, dan ketenagakerjaan di Jawa Barat.
\end{abstract}

Kata Kunci: Prosedur Penetapan Upah Minimum; Kesejahteraan Masyarakat.

\section{INTRODUCTION}

Everyone has the right to a decent life. The provisions of Article 1 paragraph (3) of the 1945 Constitution of the Republic of Indonesia note the State of Indonesia is a state based on the rule of law. Adhering to decentralization system in the governance administration, as illustrated in Article 18 paragraph (1) of the 1945 Constitution of the Republic of Indonesia, the Unitary State of the Republic of Indonesia is divided into provinces and a province is divided into districts and cities in which each 
province, district and city has its own regional administration, regulated by law ${ }^{1}$. Implementing a minimum wage policy that can improve workers' welfare requires enforcement and strict sanctions for employers who do not apply a minimum wage policy ${ }^{2}$.

Article 27 paragraph (2) of the 1945 Constitution of the Republic of Indonesia states each citizen shall be entitled to an occupation and an existence proper for a human being. Each day, humans are never separated from needs, either primary, secondary or tertiary needs, in order to maintain their lives because the ultimate goal to be achieved is the comfort of life and well-being. Yet, these needs cannot be met without efforts since everything related to needs requires cost/money. Working either carried out independently or working for a company as a worker/laborer is a form of efforts done by individuals to survive. According to Islamic law, the wage establishment for workers, in addition to minimum wage establishment, shall be based on the calculation of the minimum life of workers and their families as wage standard. ${ }^{3}$

Worker and employer have the same interests, namely the company's survival and growth. Yet, on the other hand, the relationship between them also has differences and even has the potential for conflict, especially when related to different perceptions or interpretations about the interests of each party. Workers/laborers are people working for others because there is a job to be done in which there are elements of instruction, wage and time. This relationship is developed between individual workers and employers. Worker/laborer has the right to form a workers' organization for their interests as regulated in Law No. 21 of 2000 concerning Trade Union/Labor Union and Law No. 13 of 2003 concerning Manpower. In accordance with these Laws, trade union/labor union in a company is formed by at least ten workers/laborers. Thus, it is very possible to have one or more trade unions/labor unions in a company. The purpose of forming trade union is to provide protection towards the interests of workers. This union is a social force which has social and economic functions. Yet, in practice, there are some employers who make it difficult for workers to form trade union. A company is an organization established by a person or a group of people which has function to carry out production and distribution activities to meet humans' economic needs. These production and distribution activities are carried out by combining various factors of production, namely humans, nature and capital.

An employment relationship, namely the relationship between an employer and a worker/laborer based on a work agreement, deals with aspects relating to the job, the worker's wage and the instructions or industrial relations. An industrial relation is a system of relations that take shape among actors in the process of producing goods or services in a company which consists of employers, workers/laborers, and the government. This relationship is based on the values of Pancasila and the 1945 Constitution of the Republic of Indonesia. Both workers/laborers and employers have their own rights and obligations. These rights and obligations are regulated in Law No. 13 of 2013 concerning Manpower. These industrial relations need to be regulated in order to create productivity or company performance in the form of increasing productivity and welfare for both workers/laborers and employers. The increased company's productivity and worker's/laborer's welfare are interrelated and inseparable from one another. The legal protection for child workers in the informal sector in Kediri is not in accordance with the legal protection of labor as regulated in the Manpower Act. ${ }^{4}$

1 Ridwan H.R., Hukum Administrasi Negara, Rajawali Pers, Jakarta, 2016, p 17.

2 Devanto Shasta Pratomo dan Putu Mahardika Adi Saputra, "Kebijakan Upah Minimum Untuk Perekonomian Yang Berkeadilan: Tinjauan UUD 1945”. Journal of Indonesian Applied Economics Vol. 5 No. 2 Oktober 2011, 269-285.

${ }^{3}$ Edwin Hadiyan, "Sistem Pengupahan Tenaga Kerja Ditinjau dari Prinsip Muamalah dan Undang-Undang Nomor 13 Tahun 2003 Tentang Ketenagakerjaan"Jurnal Bisnis dan Manajemen (JBIMA). ISSN : 23389729.Vol.3, No. 1, Maret 2015. 24-33.

${ }^{4}$ Netty Endrawati, "Perlindungan Hukum Terhadap Pekerja Anak Di Sektor Informal”, Jurnal Dinamika Hukum Vol. 12 No. 2 Mei 2012.270-283. 
Company productivity must start with performance productivity. Yet, it is only possible if it is supported by the conditions of workers/laborers that are prosperous or at least there is a real hope for them to improve their prosperity in the future. This is in line with the mandate of Article 92 of Law No. 13 of 2003 concerning Manpower that employers shall formulate the structure and scale of wages by taking into account the functional and structural positions and ranks, the occupation, years of work, education and competence of the workers/laborers; employers shall review their workers'/laborer' wages periodically by taking into account their company's financial capability and productivity; and the provisions concerning the structure and scale of wages shall be determined and specified with a Ministerial Decision. A wage is the most vulnerable aspect in industrial relations. In one hand, wage is the worker'/laborer' right as a compensation for services or labor provided. On the other hand, employer views wage as costs. Therefore, the government set minimum wage in order to provide protection to workers/laborers over the amount of income they receive. Wage is an income given by the employers to the workers for their achievement in the form of works or services that have been or will be performed by the workers and expressed in the form of money. The amount is determined by legislations and is paid on the basis of a work agreement between the employer and the worker.

A wage is a worker's right that should be able to meet his needs. Wage systems need to be developed with attention to the balance between work productivity and workers' needs which are always increasing from time to time. Yet, in this case, the establishment of minimum wage and the increase of minimum wage that are too drastic will harm companies, while the increase that is too flat does not benefit workers. Therefore, the minimum wage can at least be directed at achieving wages that are in line with the needs for minimum living. The factor of company's ability that has not been able to provide minimum wage adjusted to the decent living needs is important to be considered as mandated by Law No. 13 of 2003 concerning Manpower. Basically, it is necessary to consider the impact of minimum wage establishment on company growth. Yet, the establishment of minimum wage that only considers the interests of the workers/laborers is detrimental to the survival of the company. This is due to the fact that there are two sides that need to get fair protection. In this sense, workers/laborers need adequate wages to meet their daily needs, while companies need to get guarantees in the improvement and development of their businesses.

The philosophical foundation of manpower is outlined in the Preamble of the 1945 Constitution that some of the goals of the state are to advance general prosperity, to develop the nation's intellectual life, and and to contribute to the implementation of a world order based on freedom, lasting peace and social justice. It means that the government must create prosperity and, at the same time, make every citizen have a fair share in accordance with their services and needs. The state must give high priority to the placement of workers and implement strategies to expand employment opportunities so that everyone who is able and willing to work can work productively in accordance with his skill and desire. Basically, the purpose of bureaucratic reform is to accelerate the achievement of good governance and to support regional governments in improving their performance so that general prosperity can be realized ${ }^{5}$.

In fact, currently, there are still limited job opportunities so that the unemployment rate continues to rise. This condition shows that the government cannot overcome the problem of unemployment yet. The negative impact of the number of unemployment is the higher crime rates. Basically, the issues raised in this study are the different interests between workers/laborers and companies as well as the relation between the minimum wage based on Law No. 13 of 2003 concerning Manpower and company growth. Based on the aforementioned description, the problems raised in this study are formulated into

\footnotetext{
5 Haris Budiman dan Suwari Akhmaddhian, "Implementasi Reformasi Birokrasi Bidang Perizinan Pananaman Modal di Kabupaten Kuningan” Jurnal Unifikasi, ISSN 2354-5976 Vol. 1 No. 1 Oktober 2013.1-19.
} 
the following questions: 1) What is the procedure of minimum wage establishment based on Law No. 13 of 2003 concerning Manpower? and 2) How is the implementation of minimum wage establishment based on Law No. 13 of 2003 in Kuningan District?

\section{RESEARCH METHODS}

The method used in this study was a descriptive analytical method with an empirical juridical approach. This study began with field and literature study. The data collection techniques used in this study were interview and literature study. Meanwhile, the data collection instruments were in the form of observation sheet and interview questions. The collected data were then analyzed by applying qualitative analysis techniques.

\section{RESULTS AND DISCUSSION}

\section{The Procedure of Minimum Wage Establishment Based on Law No. 13 of 2003 concerning Manpower}

To provide a decent life for workers and to ensure the survival of companies, the government develops policies regulating wage establishment mechanism in labor market. As stated in Article 1 paragraph 30 of Law No. 13 of 2003 concerning Manpower, a wage is the right of the worker/laborer that is received and expressed in the form of money as a compensation from the entrepreneur or the employer for the worker/laborer whose amount is determined and paid according to a work agreement, a deal or a legislation, including allowances for the worker/laborer and his families for a job or service that has been or will be performed. The mechanism of wage establishment is regulated in Law No. 13 of 2003 concerning Manpower consisting of minimum wage, wage agreement, implementation of wage structure and scale, and periodic wage reviews. Government Regulation No. 78 of 2015 concerning Wage which is a substitute for Government Regulation No. 8 of 1981 concerning Wage Protection states that wage consists of wage without allowance, basic wage and fixed allowance, or basic wage, fixed allowance, and non-fixed allowance.

In Government Regulation No. 78 of 2015 concerning Wage, it is stated wage policy aims at the achievement of income that can fulfill decent living needs for worker/laborer. Decent income is the amount of income or earnings received by worker/laborer from their work so they can fulfill the basic needs of theirs and their families reasonably. The establishment is intended to guarantee that the amount of wage received by worker/laborer does not fall below the minimum living needs as a result of labor supply which far exceeds the demand for labor in labor market. The minimum wage policy aims to guarantee the worker's income to not lower than a certain level, increase working productivity, and develop company with more efficient production methods ${ }^{6}$.

In Government Regulation No. 78 of 2015 concerning Wage, it is explained that employer is obligated to pay the wage at the time as agreed between employer and worker/laborer. In the event of the day or date which has been agreed upon on holiday or day off, or weekly off day, the payment of wage is regulated in Work Agreement, Company Regulation or Collective Bargaining Agreement. A wage given to a worker in a production activity is basically a reward or a compensation given by the employer to the worker for his achievements in the production activities. The terms salary and wage are often used interchangeably causing them to be considered to have a same meaning. Yet, basically, the two terms have different meaning. Salary is given to administrative workers on a regular basis each month, while wage is given to field workers per hour, per day or per product.

Based on Article 1 paragraph 30 of Law No. 13 of 2003 concerning Manpower, a wage is the right of the worker/laborer that is received and expressed in the form of money as a compensation from the entrepreneur or the employer for the worker/laborer whose amount is determined and paid according to

6 Sonny Sumarsono, Manajemen Koperasi, Graha Ilmu, Yogyakarta, 2008, p. 63. 
a work agreement, a deal or a legislation, including allowances for the worker/laborer and his families for a job or service that has been or will be performed.

According to Article 88 of Law No. 13 of 2003, it is explained that every worker/laborer has the right to earn a living that is decent from the viewpoint of humanity. In order to enable the worker to earn a living that is decent from the viewpoint of humanity, the government establishes a wage policy that protects the worker/laborer. The wage policy that protects workers/laborers includes minimum wages; overtime pay; wages that are payable to the worker during his absence from work due to illness; wages that are payable to the worker during his absence from work because of activities outside his job that he has to carry out; wages payable to the worker during his absence from work because he uses his right to take a rest; the form and method of the payment of the wages; fines and deductions from wages; things that can be calculated with wages; proportional wage structure and scale; wages for the payment of severance pay; and wages for calculating income tax. The government establishes/sets minimum wages based on the decent living needs by taking into account productivity and economic growth.

According to Article 89 of Law No. 13 of 2003 concerning Manpower, it is described that the minimum wages may consist of provincial or district/city-based minimum wages and sector-based minimum wages within a given province or district/city. The establishment of minimum wage is directed towards meeting the decent living needs. The minimum wage is established by the Governor after considering the recommendations provided by Provincial Wage Councils and/or District Heads/Mayors. The components of and the implementation of the phases of achieving the decent living needs are specified and determined with a Ministerial Decision. The procedure of minimum wage establishment uses the applicable legislations or laws so that it is in accordance with the theory of the state based on the rule of law stated in the 1945 Constitution. The state is a legal subject in the sense of rechstaat or a legal entity of the republic contributing to the realization of quality law reform and development in Indonesia.

\section{The Implementation of Minimum Wage Establishment Based on Law No. 13 of 2003 in Kuningan District}

The mechanism of minimum wage establishment in Kuningan District based on the result of an interview conducted with Mr. Asep Samsu Ramli as the Head of Labor and Social Security at the Office of Manpower and Transmigration is described below. The mechanism adopted by the District Wage Council in establishing district minimum wage is to schedule a plenary meeting that must be attended by all members of District Wage Council of Kuningan as regulated in the Kuningan District Head Decision No: 560/KPTS.375-Disosnaker/2016. The members of District Wage Council who must attend the plenary meeting are the structural staff of the Manpower Office, academicians, employers, BPS, Head of Economics of Kuningan as well as trade unions. Standard Operational Procedure (SOP) that is carried out is by distributing the invitation of the plenary meeting to all members of District Wage Council to establish district minimum wage. Before conducting this meeting, the District Wage Council has conducted survey concerning components of the decent living needs (KHL). In the plenary meeting, all members discussed the value of wages to be established that is based on the calculation formula outlined in Government Regulation No. 78 of 2015 concerning Wage. The minimum wage calculation formula is current year minimum wage added by the multiplication result between current year minimum wage with the sum of current year national inflation rate and current year gross domestic product growth level.

After deciding the value of district minimum wage, the District Wage Council sign all documents that have been discussed and then submit it to the District Head to recommend the district minimum wage to the Governor. After the Governor's Decree on the district minimum wage has been issued, the Office of Manpower shall socialize the new district minimum wage to a number of companies and 
business entities. The implementation of minimum wage establishment based on Law No. 13 of 2003 in Kuningan District can be explained in more detail in the following sub-sections.

\section{a. Fields Related to Minimum Wages Establishment}

The minimum wage establishment is intended to guarantee that the level of wage received by worker/laborer does not fall below the minimum living needs as a result of labor supply which far exceeds the demand for labor in labor market. The government is one of the three elements in the wage council that has duty to determine the value of decent living needs as a basis for establishing district minimum wage in accordance with Presidential Decision No. 107/2004 concerning Wage Council.

The government's task in establishing the value of decent living needs is carried out by the Office of Manpower and Transmigration, especially by the Field of Labor Relations and Protection. This field has its own duties and functions. The main duty of the Head of Labor Relations and Protection in accordance with Article 19 of Presidential Decision No. 107 of 2004 is to carry out part of the duties of the head of office in leading, coordinating, establishing, and controlling tasks relating to labor relations and protection which include industrial relations and working conditions, labor inspection and protection as well as licensing. In carrying out its main duties, the Head of Labor Relations and Protection has functions to:

1) Prepare materials for formulating policies in order to support the labor relations and protection's tasks which include industrial relations and working conditions, labor inspection and protection as well as licensing;

2) Prepare materials for developing work programs in the field of labor relations and protection which include industrial relations and working conditions, labor inspection and protection as well as licensing;

3) Prepare materials for coaching, controlling and technical guidance in the field of labor relations and protection which include industrial relations and working conditions, labor inspection and protection as well as licensing;

4) Prepare coordinating materials and facilitate tasks in the field of labor relations and protection which include industrial relations and working conditions, labor inspection and protection as well as licensing;

5) Carry out evaluation and reporting of tasks in the field of labor relations and protection which include industrial relations and working conditions, labor inspection and protection as well as licensing;

6) Carry out other tasks given by the Head of Manpower and Transmigration Office.

On the other hand, the duties and functions concerning wages are carried out by the field of Industrial Relations and Working Conditions in accordance with Article 21 and Article 22 of the District Head Regulation No. 5 of 2011. The head of industrial relations and working conditions has the main duties of carrying out part of the duties of the Head of Labor Relations and Protection in leading, coordinating, establishing, and controlling tasks in the field of industrial relations and working conditions which include establishing and developing industrial relations; regulating information systems; authorizing, registering, and/or establishing organizations of workers, employers and tripartite institutions; providing guidance and counseling concerning industrial relations; and formulating administrative requirements for work and licensing. Meanwhile, the functions carried out by the Head of Industrial Relations and Working Conditions are:

1) Preparing materials for developing work programs in the field of industrial relations and working conditions which include establishing and developing industrial relations, regulating information systems, authorizing, registering, and/or establishing organizations of workers, employers and tripartite institutions, providing guidance and counseling concerning industrial relations, and formulating administrative requirements for work and licensing; 
2) Collecting materials for coordinating the preparation of work programs in the field of industrial relations and working conditions which include establishing and developing industrial relations, regulating information systems, authorizing, registering, and/or establishing organizations of workers, employers and tripartite institutions, providing guidance and counseling concerning industrial relations, and formulating administrative requirements for work and licensing;

3) Processing/analyzing materials as well as providing advice/input for evaluation and reporting system in the field of industrial relations and working conditions which include establishing and developing industrial relations, regulating information systems, authorizing, registering, and/or establishing organizations of workers, employers and tripartite institutions, providing guidance and counseling concerning industrial relations, and formulating administrative requirements for work and licensing;

4) Handling documents/materials for coordination in the field of industrial relations and working conditions which include establishing and developing industrial relations, regulating information systems, authorizing, registering, and/or establishing organizations of workers, employers and tripartite institutions, providing guidance and counseling concerning industrial relations, and formulating administrative requirements for work and licensing;

5) Carry out other tasks given by the Head of Manpower and Transmigration Office.

\section{b. Wage Protection}

Every worker has the right to get legal protection, especially regarding wage received by them in order to earn a living that is decent from the viewpoint of humanity. Thus, in this case, the government sets the minimum wage for workers. As stated in Article 90 paragraph (1) of Law No. 13 of 2003, employers are prohibited from paying wages lower than the minimum wage. The wage protection itself covers:

1) Minimum wage. As stated in Article 90 paragraph (1) of Law No. 13 of 2003 concerning Manpower, employers are prohibited from paying wages lower than the minimum wage. This is intended to ensure that workers receive an income that is decent from the viewpoint of humanity.

2) Wages during not working. In the legislation, there is a principle stating wages are not paid if workers do not work. This provision applies to all groups regardless of their working status. However, this principle also considers the reasons why workers do not work.

3) Proportional wage structure and scale. Proportional wage structure and scale are developed through the stages of job analysis, job evaluation, wage surveys, and wage line establishment. The results of job analysis are used as a reference for evaluating job positions in which the result of job position evaluation can be used to realize internal circumstances. Meanwhile, wage surveys will realize external justice so as companies can compete in labor market. In this case, the establishment of wage line is done by considering the financial capability of the company.

\section{c. Factors Considered in Establishing Minimum Wage}

The government sets minimum wages based on the decent living needs and by taking into account productivity and economic growth. In establishing the phases of achieving the decent living needs, the Governor considers the labor market conditions, the least capable businesses in the province/district/city as well as the recommendations provided by the Provincial/District/City Wage Councils.

The decent living needs is a monthly standard needs that must be met by a worker to be able to live properly both physically, non-physically, and socially. The value of the decent living needs obtained from the survey is the main reference in establishing the minimum wage, but it is not the only factor becoming a reference. This is why the minimum wage does not absolutely have to be the same as the value of the decent living needs. Yet, the establishment of minimum wage must pay attention to the level of macro productivity in the local area, the economic growth, the labor market conditions as well as the ability of the least capable businesses. 
The minimum wage is the lowest monthly wage consisting of basic wage and fixed allowance. The minimum wage is regulated in the form of a decree issued by the government regarding the obligation of companies to pay wage at least equal to the decent living needs (KHL) to the lowest level of workers by taking into account the productivity and economic growth. This establishment intends to provide protection to the lowest level of workers or workers who have a maximum working period of one year in order to earn a living that is decent from the viewpoint of humanity.

\section{d. Mechanism of Minimum Wage Establishment}

The minimum wage is established by the Governor with the consideration that the Governor is more aware of the social, economic and employment conditions in the local area. The Governor sets a minimum wage based on the recommendation provided by the Provincial/District/City Wage Councils. By considering the provisions governing the time for setting minimum wage, the Wage Council has been able to establish the timetable for discussing the value of minimum wage to be recommended to the Governor.

The establishment of minimum wage is a form of protection provided by the government to workers which is also a safety net for them to ensure that workers' wages do not fall to the lowest level. Basically, the minimum wage is established to protect wages received by low-educated workers, unskilled workers, single workers, and workers whose working period is less than one year.

\section{e. Establishment of District Minimum Wages}

The establishment of minimum wage is carried out by the Wage Councils through several stages to obtain a decent living standard. The Wage Council consists of three elements, namely government, employers and workers as well as academicians. The minimum wage is established by considering the value of the decent living needs, productivity, economic growth, the least capable businesses, and labor market conditions.

The minimum wage is established based on independent discussions and in-depth negotiations. The academicians as a neutral party in Wage Council have a very strategic role to provide input in the form of academic studies and considerations. These academic considerations given by academicians are used as a reference for Wage Council to agree on the minimum wage that will be recommended to the Governor. The establishment of minimum wage is done by considering:

1) Minimum Life Needs (KHM);

2) Consumer price index (IHK);

3) Ability, development, and sustainability of the company;

4) Wages applied in certain areas and between regions;

5) Labor market conditions;

6) Level of economic development and per capita income.

The process of establishing district minimum wage is carried out through six stages, namely:

1) Survey of market needs value. Firstly, team of decent living needs survey is formed by the Wage Council. This team works from January to August in which this team establishes the value of the decent living needs in each month. From these eight months, a figure of decent living needs is established. Meanwhile, the value of the decent living needs in the ninth to twelfth months is predicted by the Central Bureau of Statistics with reference to the last eight months decent living needs. Of the twelve values of the decent living needs, the average is taken to be the value of the decent living needs. The data collection process of community needs values is carried out in traditional markets to get the value of minimum living needs in the district area.

2) Establishment of the living needs value. The Wage Council issues a Decree regulating the value of the decent living needs from the result of community needs survey for twelve months.

3) Establishment of District Minimum Wage. The value of the decent living needs is used to establish the value of district minimum wage in the following year. Each year, there are agreements from the three elements in establishing the value of minimum wage seen from how much the percentage of 
the minimum wage is compared to the value of the decent living needs established by the Wage Council. In 2012, the district minimum wage is only $94.6 \%$ of the value of the decent living needs. In 2013, its percentage increased to $97 \%$ and $100 \%$ in 2014.

4) The Wage Council proposes the value of district minimum wage to be considered by the District Head.

5) The District Head submits the recommendation provided by the wage council concerning the value of district minimum wage to the Governor.

6) The Governor issues a Governor Decree regulating the establishment of district minimum wage. The value of the minimum wage is in accordance with the recommendation provided by the wage council.

\section{f. District Minimum Wage}

Based on the Decree issued by the Governor of West Java, the Minimum Wage of Kuningan District was set at Rp. 1,224,000 in 2015, Rp. 1,364,760 in 2016, and Rp 1,447,352 in 2017.

The discussion on the implementation of minimum wage establishment based on Law No. 13 of 2003 in Kuningan District is described in the following sub-sections.

\section{a. General Discussion}

Wage is one of the most strategic areas in working relations in companies so that the amount of wage paid by employers depends on the contribution given by workers to employers. The principle of 'no work no pay' exists in wage system meaning that if the worker does not do his work, he has no contribution in making profits at that time so that the worker will not be paid.

The minimum wage policy, which is one of the wage policies, is intended to provide a guarantee ensuring that wages do not fall at the lowest level due to an imbalance between labor demand and supply. This wage protection is in accordance with the aims and objectives of the formation of the Indonesian State.

The government provides a legal protection since manpower has a crucial role as a national development agent in carrying out national development. Article 27 paragraph (2) of the 1945 Constitution states each citizen shall be entitled to an occupation and an existence proper for a human being. Moreover, Article 28 D paragraph (2) of the 1945 Constitution states every person is entitled to an occupation as well as to get income and a fair and proper treatment in labor relations.

In the same sense, Article 88 paragraph (1) of Law No. 13 of 2003 concerning Manpower notes every worker/laborer has the right to earn a living that is decent from the viewpoint of humanity. It means that the amount of income or earnings received by worker/laborer from their work shall be able to fulfill the basic needs of theirs and their families reasonably. This is one form of protections provided by the government to the wage received by workers.

Worker protection can be done by making demands, increasing the recognition of human rights, providing physical and technical protection as well as social and economic norms applicable in working environment. Specifically, these protections include: ${ }^{7}$

1) Work safety norms which include work safety related to machinery, aircraft, working tools, work processes and ways of doing work.

2) Norms of occupational and company health which include maintenance and enhance workers' health status.

3) Work norms which include protection of workers relating to working time, wage system, morality, worship and work morale to ensure high work efficiency and provide treatment in accordance with human dignity and morale.

4) Rights for compensation and rehabilitation due to accidents or occupational diseases.

In this regard, Imam Soepomo divides the protection of workers into three types, namely: ${ }^{8}$

7 Zainal Asikin, et al., Dasar-Dasar Hukum Perburuhan, PT. Rajagrafindo Persada, Jakarta, 2013, pp. 75-76. 
1) Economic protection which is a type of protection relating to efforts to provide an income that is able to fulfill the basic needs of the workers and their families.

2) Social protection which is a type of protection relating to social enterprises in which its purpose is to enable the workers to develop their lives as human beings and as community and family members.

3) Technical protection which is a type of protection relating to efforts to protect workers from accidents caused by working tools or processed materials.

b. Discussion on Wage Protection

By referring to Article 88 paragraph (1), Article 88 paragraph (2) states that in order to enable the worker to earn a living that is decent from the viewpoint of humanity, the government establishes a wage policy that protects the worker/laborer. This Article clearly provides protection for workers concerning income they earn for the work they do. The decent wage for humanity is further regulated in the provision of minimum wage that is directed towards meeting the decent living needs.

In Article 88 paragraph (4), it is declared that the government sets the minimum wage based on the decent living needs by taking into account productivity and economic growth. In establishing the minimum wage in accordance with Article 89 paragraphs (1) and (2), the minimum wages may consist of provincial or district/city-based minimum wages and sector-based minimum wages within a given province or district/city which are directed towards meeting the decent living needs.

c. Discussion of Factors Considered for Minimum Wage Establishment

Referring to Article 88 paragraph (4) of Law No. 13 of 2003, it is stated that the government sets the minimum wage based on the decent living needs by taking into account several matters, including:

1) Productivity. Productivity refers to macro workers' productivity in the local area. This productivity development can be an indicator for increasing the value of minimum wage since worker contributes to increasing added value so that there should be a part of increasing productivity that must be returned to the worker.

2) Economic growth. Economic growth refers to the growth showing an increase in added value generated by the local community. Worker is a part of community that has the right to enjoy the results of economic growth through an increased wage.

3) Marginal Enterprises Capability. Based on Law No. 20 of 2008 concerning Micro, Small, and Medium Enterprises, marginal enterprises are micro enterprises having the following criteria:

a) Having net assets of Rp. 50,000,000 exclusive of land and building of their place of business;

b) Having maximum annual sales proceeds of Rp. 300,000,000 per year. If the establishment of minimum wage does not pay attention to marginal enterprises groups, it tends to kill theses business groups. The minimum wage that is too high will affect the group of workers who work in marginal enterprises. There will be a tendency for them to ask increased wage in accordance with increased minimum wage. This condition will kill these business groups.

4) Labor Market Conditions. In labor market conditions where there is excess labor, it is very difficult to improve labor conditions, including wage. This is due to the fact that economic law will apply in labor market. For example, if the number of job seekers is higher than the number of available jobs, there will be a tendency for prospective workers to be paid a relatively low wage. Thus, the establishment of minimum wage is intended to provide protection for workers, but still consider the employers' ability. This is very important because both worker and employer need each other. In this case, the welfare of both parties, especially worker, may only be fulfilled if it is supported by a certain level of productivity. In Article 5 paragraph (3) of the Regulation of the Minister of Manpower and Transmigration No. PER./17/MEN/VII/2005 concerning The Components of and The Implementation of the Phases of Achieving the Decent Living Needs, it is stated that in

$8 \quad$ Ibid. 
establishing the phases of achieving the decent living needs, the Governor shall consider the labor market conditions, the least capable businesses in Province/District/City as well as the recommendations provided by the Provincial/District/City Wage Councils.

\section{d. Discussion of Minimum Wage Establishment Mechanisms}

Referring to the Regulation of the Minister of Manpower and Transmigration No. PER17.MEN/VIII/2005 concerning The Components of and The Implementation of the Phases of Achieving the Decent Living Needs, it is regulated that the district minimum wage shall be in accordance with the applicable mechanism. The decent living needs is a monthly standard needs that must be met by a worker to be able to live properly both physically, non-physically, and socially. There are 46 types of needs consisting of 7 components, namely food and drink, clothing, housing, education, health, transportation, recreation and savings.

When the establishment of minimum wage is seen from the perspective of each party, both in terms of worker and employer, there will be a different perspective. From workers' point of view, wage is only seen from the comparison between the amount of wage they receive and their basic needs. However, from employers' point of view, wage is seen from the comparison between the amount of wages they shall pay and the number of workers they have in the company.

The minimum wage is an element that is full of political content in labor policy. Minimum wage is used by government to develop economic and social policies. Its supporters say that the minimum wage can increase wage of low-income workers. Meanwhile, its opponents question its effects on employment because they think that the established minimum wage is not relevant with the real labor market conditions.

Empirically, there is a conflict between worker and employer concerning wage policies. In one hand, employer wants to pay worker as low as possible to reduce production costs, but on the other hand, worker wants high income to improve their welfare. Thus, to handle this issue, the government then establishes the minimum wage as a bridge for facilitating the interests of both parties.

In reality, a low or moderate minimum wage will have a positive impact on economy in general. In this case, employers can provide job opportunities for job seekers as well as increase economic competition at the same time. Hence, this will result in a decrease number of unemployment. Conversely, a high minimum wage will have a negative effect on economy. Here, employers will reduce the number of workers in order to reduce production costs due to high minimum wage that must be paid. Thus, it is clear that this condition becomes a reason causing the establishment of minimum wage is full of political content.

The establishment of minimum wage is carried out by the Governor as stipulated in Article 89 paragraph (3) that the Minimum Wage as referred to in paragraph (1) is established by the Governor by taking into account the recommendations provided by Provincial Wage Council and/or Head District/Mayor.

e. Discussion on District Minimum Wage Establishment

The formulation of wage policies carried out by the government is based on the recommendations provided by Wage Councils. Article 98 of Law No. 13 of 2003 is the basis for the formation of Wage Council which was then followed by the issuance of Presidential Decision No. 107 of 2004 with a hope to minimize problems faced by Wage Council, particularly technical problems relating to procedure of formation, composition and requirements of membership, procedures of appointment and termination of membership as well as duties and working procedures of Wage Council.

Wage council consists of several elements, namely government, trade unions, employers' organizations, and academicians. The duties and functions of the District/City Wage Council based on Article 38 of Presidential Decision No. 107 of 2004 concerning Wage Council are as follows:

1) Provide advice and recommendation to the District Head/Mayor in order to:

a) Propose District Minimum Wage (UMK) or District/City Sectoral Minimum Wage (UMSK); 
b) Implement wage system at the District/City level;

2) Prepare materials for the formulation of national wage system.

The minimum wage proposed by wage council is a result of survey conducted in traditional markets. In this case, the wage council has functions to form a survey team, determine specific types of need, determine price deviation, prepare questionnaires, select survey site, determine criteria for respondents, and hold a coaching for survey team members. In terms of factors considered for establishing minimum wage, the Wage Council conducts discussions for the following matters:

1) Decent Living Needs (KHL);

2) Effect of economic growth condition on KHL value and minimum wage;

3) Effect of productivity on KHL value and minimum wage;

4) Ability of the least capable businesses to pay wage and its effect on the amount of minimum wage;

5) Available job opportunities compared to the number of job seekers and the effect of minimum wage on the expansion of job opportunities.

R. Djokosutomo argues that the rule of law according to the 1945 Constitution is the state based on the rule of law. The state is a legal subject in the sense of rechstaat (a legal entity). Since the state is seen as a legal subject, then if it is guilty, it can be prosecuted in the court. The term rechstaat which is interpreted as the rule of law became popular in Europe since the 19th century, although the idea has been existed for a long time. ${ }^{9}$ Legislative theory is a theory studying and analyzing the ways or techniques of formulating legislations that cover the stages of planning, drafting, discussing, ratifying and enacting. ${ }^{10}$. This theory is used to study and analyze whether the established legislations are in accordance with the theory of legislation, for example, whether the developed laws are in accordance with the hierarchy of legislation or not. In formulating legislation ${ }^{11}$, it is known a theory of the level of law (stufentheorie) proposed by Hans Kelsen. He argues that legal norms are tiered and layered in a hierarchy in the sense of an applicable norm is sourced and based on the higher norms. This rule is applicable to all norms until they arrive at a norm that cannot be explored further and is hypothetical and fictitious, namely the basic norm (grundnorm).

Further, Rawls proposed a theory of justice which formulates the principles governing the distribution of rights and obligations among all community members. The emphasis on the issue of rights and obligations, which is based on a concept of justice for social collaboration, shows that Rawls's theory of justice focuses on how to distribute rights and obligations equally in a community so that all community member has the same opportunity. ${ }^{12}$ Referring to the aforementioned general principle, Rawls formulates the following two principles of justice:

1) Everyone must have the same right to the most basic freedoms.

2) Socioeconomic inequalities must be regulated in such a way in order to benefit the most disadvantaged people and all positions are open to everyone.

The description of Rawls's theory of justice and Law No. 13 of 2003 concerning Manpower is closely related in the sense of worker/laborer has equal right and protection for the sake of realizing general prosperity. Worker protection is intended to guarantee the basic rights of worker/laborer as well as to guarantee equality in job opportunities and treatment to realize general prosperity while considering business world growth. Kuningan District Regulation No. 15 of 2011 describes that the principle of manpower implementation is open, free, objective, fair and equal without discrimination. The purposes of manpower implementation are providing services to job seekers to get a job in

\footnotetext{
9 Philipus M. Hadjon, Kedaulatan Rakyat, Negara Hukum dan HAM, Media Pratama, Jakarta, 2008, p. 72.

10 Anonym, Teori Legislasi, 2013, retrieved from: http://beritatransparansi.com on 2 March 2017.

11 Anonym, Teori Hierarki, 2012, retrieved from: http://rajawaligarudapancasila.blogspot.co.id on 7 March 2017.

12 Nadya Rakasiwi, Teori Keadilan, 2016, retrieved from: http://nadyarakasiwi.blogspot.co.id on 7 March 2017.
} 
accordance with their talents, interests and skills; producing competent workers who are able to compete in labor market; and providing protection to workers in realizing global prosperity.

Kuningan District Regulation No. 15 of 2011 concerning Manpower Implementation states that in terms of wage, every worker/laborer has the right to receive an income to earn a living that is decent from the viewpoint of humanity in accordance with the applicable legislations. Thus, every person employed as a housekeeper is entitled to a reasonable income. According to Kuningan District Regulation No. 15 of 2011, district minimum wage is established by the Governor by taking into account the recommendations provided by District Head; employers are prohibited from paying wage lower than district minimum wage; employers who are unable to pay wage in accordance with district minimum wage can submit a postponement to Head District; and the suspension procedures are determined by Head District Decision. Data on manpower plays an important role in development planning. Thus, it is impossible to implement a development program without this data. The more complete and accurate the data is, the easier and more precise the development will be. What is meant by manpower is the size of population that can be included in economic activities. The International Labor Organization (ILO) declares that the determination of a person could or could not be involved in economic activities is based on age. ${ }^{13}$

Workforce is the productive age population aged 15-64 years-old who already have work but are temporarily not working or who are actively looking for work. Thus, the workforce consists of people who have work, have permanent work but are temporarily not working, and have no work at all but are actively looking for work. Work is defined as carrying out an activity to produce goods or services with a view to earn income in the form of money and/or goods. Manpower development in Indonesia is based on Pancasila and the 1945 Constitution of the Republic of Indonesia ${ }^{14}$. This development has many dimensions and relationships with various parties, namely government, employers and workers/laborers. Therefore, manpower development is carried out in an integrated manner in the form of mutually supportive work. The objectives of manpower development are as follows: ${ }^{15}$

1) Empower workers optimally and humanely.

2) Provide protection to workers in realizing general prosperity.

3) Realize balance between job opportunities and labor supplies based on the needs for national and regional development.

4) Improve welfare of the workers and their families.

Welfare is a compensation (both material and non-material) provided by the company based on some considerations. The compensation is given with an aim to maintain and improve the physical and mental condition of workers which will then have an impact on an increased productivity. The compensation can be seen as further assistance to workers, especially if the compensation is given to those who are sick or is given in the form of shares, insurance, health insurance, and retirement allowance. $^{16}$

The problem of social welfare shows that there are citizens whose basic needs are not fulfilled reasonably since they have not received social services from the state ${ }^{17}$. As a result, there are some citizens who cannot carry out their social functions so that they cannot have a decent and dignified life. According to Law No. 11 of 2009, social welfare is a condition where citizen's material, spiritual and social needs are met to be able to develop themselves and live properly so that they can carry out their social functions. The fulfillment of workers' needs and welfare need to be considered by employers so

Elisa, Teori Ketenagakerjaan, 2014, retrieved from: http://elisa.ugm.ac.id on 7 March 2017.

Ibid.

Ibid.

16 Malayu S.P. Hasibuan, Manajemen Sumber Daya Manusia, Edisi Revisi, Bumi Aksara, Jakarta, 2008, pp. $183-185$

17 Ibid. 
that the workers' potential as company's assets can be optimized. In addition to affecting the workers' performance, low wage or income can also lead to various deviations, such as workers use their working time for other jobs in order to earn extra income or workers steal products. These conditions are absolutely very detrimental for the company.

\section{CONCLUSION}

Based on the results of the analysis previously described, it can be concluded that:

1. According to Article 1 paragraph 30 of Law No. 13 of 2003 concerning Manpower, a wage is the right of the worker/laborer that is received and expressed in the form of money as a compensation from the entrepreneur or the employer for the worker/laborer whose amount is determined and paid according to a work agreement, a deal or a legislation, including allowances for the worker/laborer and his families for a job or service that has been or will be performed. The procedure of minimum wage establishment is based on Law No. 13 of 2003 concerning Manpower in which the establishment of minimum wage is directed towards meeting the decent living needs. The minimum wage is determined by the Governor after considering the recommendations provided by Provincial Wage Council and/or District Heads/Mayors, in this case is District Wage Council of Kuningan and District Head of Kuningan. The components of and the implementation of the phases of achieving the decent living needs are specified and determined with a Ministerial Decision. The establishment is intended to guarantee that the amount of wage received by worker/laborer does not fall below the minimum living needs as a result of labor supply which far exceeds the demand for labor in labor market. The minimum wage policy aims to guarantee the worker's income to not lower than a certain level, increase working productivity, and develop company with more efficient production methods ${ }^{18}$.

2. The implementation of minimum wage establishment which is based on Law No. 13 of 2003 in Kuningan District is quite good since the minimum wage establishment is regulated by the Governor with the consideration that the Governor is more aware of the social, economic and employment conditions in West Java. The Governor establishes the minimum wage based on recommendations provided by the Provincial/District/City Wage Councils. By considering the provisions governing the time for setting minimum wage, the Wage Council has been able to establish the timetable for discussing the value of minimum wage to be recommended to the Governor. Based on Jhon Rawls's theory of justice, the implementation of minimum wage establishment based on Law No. 13 of 2003 in Kuningan District is closely related in the sense of worker/laborer has equal right and protection for the sake of realizing general prosperity. Worker protection is intended to guarantee the basic rights of worker/laborer as well as to guarantee equality in job opportunities and treatment to realize general prosperity while considering business world growth.

\section{SUGGESTION}

Based on the conclusions, the following suggestions for related parties are provided:

1. The applicable system of minimum wage establishment is in the form of a Governor Decision so that the implementation of legal sanctions against violations cannot be carried out optimally. Therefore, in order to implement legal sanctions optimally, the establishment of minimum wage needs to be set forth in a Regional Regulation. When the minimum wage establishment is regulated in a Regional Regulation, the House of Representatives of the Republic of Indonesia will be involved in providing protection for workers/laborers.

18 Sonny Sumarsono, Loc. Cit. 
2. If parties involved in industrial relations, namely employers and workers/laborers or trade unions/labor unions, are aware of their roles and functions and are able to act fairly and wisely, the mechanism for establishing wage can be managed by both parties. This is due to the fact that employers and workers/laborers or trade unions/labor unions have the same goal, namely the company's survival and growth. Besides, the employers and workers/laborers or trade unions/labor unions are the ones who know the conditions and capabilities of the company.

\section{REFERENCES}

Devanto Shasta Pratomo and Putu Mahardika Adi Saputra. 2011. "Kebijakan Upah Minimum Untuk Perekonomian Yang Berkeadilan: Tinjauan UUD 1945". Journal of Indonesian Applied Vol. 5 No. 2 Oktober 2011, 269-285.

Edwin Hadiyan. 2015. "Sistem Pengupahan Tenaga Kerja Ditinjau dari Prinsip Muamalah dan UndangUndang Nomor 13 Tahun 2003 Tentang Ketenagakerjaan"Jurnal Bisnis dan Manajemen (JBIMA). ISSN: 2338-9729.Vol.3, No. 1, Maret 2015. 24-33.

Haris Budiman and Suwari Akhmaddhian, 2013. "Implementasi Reformasi Birokrasi Bidang Perizinan Pananaman Modal di Kabupaten Kuningan" Unifikasi : Jurnal Ilmu Hukum, ISSN 2354-5976 Vol. 1 No. 1 Oktober 2013.1-19.

Malayu S.P. Hasibuan. 2008. Manajemen Sumber Daya Manusia, Edisi Revisi, Bumi Aksara, Jakarta.

Netty Endrawati. 2012. "Perlindungan Hukum Terhadap Pekerja Anak Di Sektor Informal", Jurnal Dinamika Hukum Vol. 12 No. 2 Mei 2012.270-283.

Philipus M. Hadjon. 2008. Kedaulatan Rakyat, Negara Hukum dan HAM, Media Pratama, Jakarta.

Ridwan H.R. 2016. Hukum Administrasi Negara, Rajawali Pers, Jakarta.

Sonny Sumarsono. 2008. Manajemen Koperasi, Graha Ilmu, Yogyakarta.

Zainal Asikin dkk. 2013. Dasar-Dasar Hukum Perburuhan, PT. Rajagrafindo Persada, Jakarta. 